\title{
Level of adrenomedullin in cases with adrenal defficiency and its relation to mortality in patients with sepsis
}

\author{
Baran BALCAN ${ }^{1}$ \\ Şehnaz OLGUN ${ }^{2}$ \\ Türkay AKBAŞ ${ }^{3}$ \\ Emel ERYÜKSEL ${ }^{2}$ \\ Sait KARAKURT ${ }^{2}$
}

${ }^{1}$ Clinic of Chest Diseases, Baskent University Istanbul Hospital, Istanbul, Turkey

${ }^{1}$ Başkent Üniversitesi Tıp Fakültesi, istanbul Hastanesi, Göğüs Hastalıkları Kliniği, istanbul, Türkiye

2 Division of Intensive Care, Department of Chest Diseases, Faculty of Medicine, Marmara University, Istanbul, Turkey

${ }^{2}$ Marmara Üniversitesi Tıp Fakültesi, Göğüs Hastalıkları Anabilim Dalı, Yoğun Bakım Bilim Dalı, Istanbul, Türkiye

${ }^{3}$ Division of Intensive Care, Department of Internal Medicine, Faculty of Medicine, Istanbul, Turkey

${ }^{3}$ Marmara Üniversitesi Tıp Fakültesi, iç Hastalıkları Anabilim Dalı, Yoğun Bakım Bilim Dalı, Istanbul, Türkiye

\section{SUMMARY}

Level of adrenomedullin in cases with adrenal defficiency and its relation to mortality in patients with sepsis

Introduction: The aim of this study was to determine the prognostic value of adrenomedullin, after evaluation of adrenal function in sepsis patients. We also evaluated other prognostic factors such as APACHE II score, proBNP, and CRP and their prediction in mortality.

Materials and Methods: This is a prospective, observational study. We enrolled 48 patients, who were admitted to the intensive care unit due to sepsis according to surviving sepsis campaign criteria.

Results: ADM median value was $60.8 \mathrm{ng} / \mathrm{L}$ in patients with normal adrenal function, and $20.1 \mathrm{ng} / \mathrm{L}$ in patients who had adrenal deficiency. With adequate adrenal response there was a linear and statistically significant relationship between adrenomedullin and mortality $(p<0.001)$. The median ADM level was $41.7 \mathrm{ng} / \mathrm{L}$ among non-survivors and $13.9 \mathrm{ng} / \mathrm{L}$ among survivors $(p<0.001)$. The median APACHE II score was 27.8 in non-survivors and 16.9 in survivors $(p=0.001)$. We also done ROC curve analysis; when ADM level was > $30.19 \mathrm{ng} / \mathrm{L}$ (sensitivity: 73.0\%, specificity: 100\%), APACHE II score was > 21 (sensitivity: 93.3\%, specificity: 84.8\%), and proBNP > $3736 \mathrm{pg} / \mathrm{mL}$ (sensitivity: $73.3 \%$, specificity: $93.9 \%$ ).

Conclusion: Without evaluation of adrenal function adrenomedullin should not be used, in predicting mortality of sepsis.

Key words: Adrenal insufficiency, adrenomedullin, sepsis

\section{ÖZET}

Sepsis nedeniyle yoğun bakıma alınan hastalarda adrenal yetmezlik varlığında adrenomedullin mortalite ilişkisi

Giriş: Bu çalışmanın amacı, sepsis hastalarında adrenal fonksiyonu değerlendirdikten sonra adrenomedullin ile mortalite arasında ilişki kurmaktır. Bunun yanında APACHE II skoru, proBNP ve C-reaktif protein (CRP) gibi diğer markerlar ile mortalite arasındaki ilişki değerlendirilmiştir.

Materyal ve Metod: Çalışma prospektif olarak sepsis nedeniyle yoğun bakım ünitesine alınmış toplam 48 hastanın verileri değerlendirilerek yapılmıştır.

\section{Yazışma Adresi (Address for Correspondence)}

Dr. Baran BALCAN

Başkent Üniversitesi İstanbul Hastanesi,

Göğüs Hastalıkları Kliniği, iSTANBUL - TURKEY

e-mail: drbaranbalcan@yahoo.com 
Bulgular: Median adrenomedüllin (ADM) değeri adrenal yanıtı tam olan hastalarda $60.8 \mathrm{ng} / \mathrm{L}$ olarak bulunmuş, adrenal yetmezlikli hastalarda $20.1 \mathrm{ng} / \mathrm{L}$ olarak tespit edilmistir. Yeterli adrenal yanıtın olduğu hastalarda adrenomedullin ile mortalite arasında doğrusal ve anlamlı bir ilişki tespit edilmiştir ( $p<0.001)$. Hayatta kalan hastalarda median ADM değeri 41.7 ng/L iken, ölen hastalarda 13.9 $n g / L$ olarak tespit edilmiştir ( $p<0.001$ ). Ölen hastalarda median APACHE II skoru 27.8 iken, hayatta kalanlarda 16.9 olarak bulunmuştur $(p<0.001)$. Bu sonuçların yanında yapmış olduğumuz ROC eğrisi analizleri ile; ADM > 30.19 ng/L, APACHE II skoru > 21 ve proBNP > $3736 \mathrm{pg} / \mathrm{mL}$ olan hastalarda mortalitenin anlamlı ölçüde yüksek olduğu tespit edilmiştir.

Sonuç: Hastalarda mortalite ve adrenomedullin arasında ilişki kurmadan önce adrenal fonksiyonun yeterli olup olmadı̆̆ı değerlendirilmelidir.

Anahtar kelimeler: Sepsis, adrenomedüllin, adrenal yetmezlik

\section{INTRODUCTION}

The mortality rate is as high as $40 \%$ in patients admitted to the intensive care unit due to sepsis (1). High mortality rate is a consequence of organ injury associated with an impaired tissue perfusion (2). Early intervention and institution of appropriate antibiotherapy and fluid resuscitation as early as possible, would be life-saving on the face of high mortality associated with sepsis.

Adrenomedullin (ADM) is a peptide initially isolated from pheochromyctoma and adrenal medulla (3). Adrenomedullin is expressed in a wide range of tissues such as; lung, adrenal medulla, ventricle, kidney and it has vasodilator effects on vascular endothelial system (4). Elevated plasma level of ADM is observed in many diseases such as chronic obstructive lung disease (COPD), asthma, heart failure, acute myocarde infarction, renal failure, etc (4). Of all these conditions, greatest increase in plasma adrenomedullin level is observed in sepsis, and increased plasma level of ADM is thought to be responsible for the hypotension in septic shock (5-7).

In previous studies it was demonstrated that ADM level is superior to some other biomarkers, such as C-reactive protein (CRP), complete blood count $(\mathrm{CBC})$, procalcitonin, pro brain natriuretic peptide (Pro BNP), acute physiology and chronic health evaluation II (APACHE II) score, in determining the mortality in sepsis (8-11). Adrenomedullin is very highly expressed in adrenal gland in both zona glomerulosa and adrenal medulla, that's why we think that for elevation of plasma ADM level there should be adequate adrenal response $(12,13)$.

Adrenomedullin is a valuable marker in the prediction of mortality in sepsis. Our primary outcome in this study was to evaluate the plasma ADM level in patients with adequate adrenal function, and the relationship of increased plasma ADM level and mortality in sepsis. And the secondary outcome of this was to evaluate the association between CRP, $\mathrm{CBC}$, proBNP, APACHE II score and mortality in sepsis patients.

\section{MATERIALS and METHODS}

This is a prospective study performed in intensive care unit (ICU) of Marmara University between January 2013 and December 2013. 48 patients (28 females, 20 male), who were admitted to the intensive care unit due to sepsis according to surviving sepsis campaign criteria, included in our study. Demographic features of the patients, comorbidities (hypertension, diabetes, cancer, etc.), and therapies initiated after admission to the intensive care unit were evaluated (Table 1). The study was approved by the ethics committee of the university, and first-degree relatives of the patients provided consent for the study. All patients admitted to the intensive care unit underwent a physical examination. Vital findings on admission (temperature, pulse, blood pressure) were recorded, and routine blood tests, biochemistry, and arterial blood gase analysis were obtained. The APACHE II score was calculated at first 24 hours of admission to ICU. Survival status was evaluated on daily controls, and by phone call at $28^{\text {th }}$ day after first admitted to ICU for patients discharged from hospital. After admission to the ICU, blood samples were collected into EDTA-tubes and biochemistry tubes, then samples were centrifuged at $3000 \mathrm{rpm}$ for 5 minutes and stored at $-80^{\circ} \mathrm{C}$. Adrenomedullin levels were measured using enzyme-linked immunosorbent assay (ELISA) method. The ADM assay is one-step sandwichcoated tube chemiluminescence immunoassay, based on Acridinium NHS-ester labeling for the detection of human ADM in unprocessed, neat plasma. For determining adrenal insufficiency, after baseline blood samples collected, basal cortisol level 
Balcan B, Olgun Ş, Akbaş T, Eryüksel E, Karakurt S.

Table 1. Diagnosis of the patients

\begin{tabular}{|c|c|c|c|c|c|c|}
\hline \multirow[b]{2}{*}{ Diagnosis } & \multicolumn{2}{|c|}{ Alive } & \multicolumn{2}{|c|}{ Dead } & \multicolumn{2}{|c|}{ Total } \\
\hline & $\mathbf{n}$ & $\%$ & $\mathbf{n}$ & $\%$ & $\mathbf{n}$ & $\%$ \\
\hline Pneumonia & 15 & 31.2 & 8 & 16.6 & 23 & 47.8 \\
\hline Malignancy & 8 & 16.6 & 0 & 0 & 8 & 16.6 \\
\hline Urinary tract infection (UTI) & 6 & 12 & 1 & 0.2 & 7 & 12.2 \\
\hline Gastrointestinal tract (GIT) bleeding & 0 & 0 & 3 & 0.6 & 3 & 0.6 \\
\hline Peritonitis & 0 & 0 & 1 & 0.2 & 1 & 0.2 \\
\hline Trauma & 0 & 0 & 1 & 0.2 & 1 & 0.2 \\
\hline Cholecystitis & 0 & 0 & 1 & 0.2 & 1 & 0.2 \\
\hline Cerebrovascular & 1 & 0.2 & 0 & 1 & 1 & 0.2 \\
\hline
\end{tabular}

measured. Then $1 \mathrm{mg}$ of synthetic adrenocorticotrophin hormone was injected intramuscularly; finally 30 minutes after injection, blood sample was collected again, and if increase in serum level of cortisol was less than $9 \mu \mathrm{g} / \mathrm{dL}$, it was accepted as adrenal insufficiency. Patients who had normal or high levels of cortisol, but did who did not respond to synthetic $\mathrm{ACTH}$, were also accepted as adrenal insufficient ones. In order to avoid interference with the cortisol levels; patients, who received methylprednisolone as part of the sepsis therapy, were not included in the study. Similarly, patients with a known class III-IV heart failure and creatinine levels above $1.5 \mathrm{mg} / \mathrm{dL}$ were excluded from the study in order to avoid interference with proBNP results, and only blood samples collected before the institution of fluid resuscitation were evaluated in the study."

SPSS 21.0 and Med Calc statistical software packages were used in the statistical analysis. Descriptive statistics (frequency, percentage, mean, standard deviation) were used to evaluate study data. The independent samples t-test was used to compare parameters between the groups. One-way ANOVA test was used to compare parameters between more than one groups, and Bonferroni test was used to determine the group that showed significant difference. The ROC curve analysis was performed to determine cut-off levels of the parameters, and sensitivity and specificity were calculated based on the cut-off value.

\section{RESULTS}

This study prospectively evaluated the medical records of 48 patients who were admitted to the intensive care unit due to sepsis. Twenty-eight (58\%) of them were females and twenty (42\%) were males. The demographics and results data are shown in Table 2. Fifteen (31\%) of
Table 2. Patient characteristics, comorbidities, and vital signs at the time they aceppted to ICU

\begin{tabular}{|lc|} 
& $\mathbf{n}$ \\
\hline Demographics & $?$ \\
Female, $\mathrm{n}(\%)$ & $28(58)$ \\
Male, $\mathrm{n}(\%)$ & $20(42)$ \\
Age & $61.5(12.4)$ \\
Examination & \\
Fever $\left({ }^{\circ} \mathrm{C}\right)$ & $37.1( \pm 1.9)$ \\
Oxygen requirement $(\%)$ & $47.9( \pm 21.3)$ \\
MAP $(\mathrm{mmHg})$ & $66.7( \pm 20.0)$ \\
Comorbidities & \\
Hipertension, $\mathrm{n}(\%)$ & $17(35)$ \\
Diabetes, $\mathrm{n}(\%)$ & $7(14)$ \\
Cardiovascular, $\mathrm{n}(\%)$ & $12(25)$ \\
Cancer, $\mathrm{n}(\%)$ & $8(16)$ \\
Findings & \\
WBC $(\mu \mathrm{L})$ & $28.0( \pm 7.2)$ \\
Htc $(\%)$ & $177.789 .9( \pm 163.320)$ \\
Plt $(\mu \mathrm{L})$ & $22.5( \pm 18.9)$ \\
ADM $(\mathrm{ng} / \mathrm{L})$ & $5107( \pm 7109)$ \\
ProBNP $(\mathrm{pg} / \mathrm{mL})$ & $169( \pm 106)$ \\
CRP $(\mathrm{mg} / \mathrm{L})$ & $58.1( \pm 47)$ \\
Cortisol $(\mu \mathrm{g} / \mathrm{dL})$ & \\
Treatment & $4832( \pm 2170)$ \\
Antibiotics $(\mathrm{n})$ & \\
Vasopressor $(\mathrm{n})$ & \\
Fluid $(\mathrm{mL})$ & \\
APACHE II & \\
\hline MAP: Mean arterial pressure, ADM: Adrenomadullin, \\
WBC: White blood cell count.
\end{tabular}

the patients were non-survivors and thirty-tree (69\%) were survivors, who were later discharged from the intensive care unit. When the relation between 
admission diagnosis and mortality was evaluated, patients admitted due to pneumonia had significantly higher mortality rate $(p=0.011)$.

The main objective of the study was, first determining adrenal deficiency and then evaluating relation between ADM level and mortality in sepsis patients. Among non-survivors median ADM level was 60.8 $\mathrm{ng} / \mathrm{L}$ in patients who had adequate adrenal response to ACTH stimulus, and $20.1 \mathrm{ng} / \mathrm{L}$ in patients who had adrenal deficiency. Relation between adrenonomedullin and mortality in situation of adrenal deficiency was not statistically significant $(p=0.068)$, on the other hand with adequate adrenal response there was linear and statistically significant relationship between adrenomedullin and mortality $(p<0.001)$. The median ADM level was $41.7 \mathrm{ng} / \mathrm{L}$ among non-survivors and $13.9 \mathrm{ng} / \mathrm{L}$ among survivors (Figure 1). In those patient who were not adrenally insufficient, there was a linear and significant relation

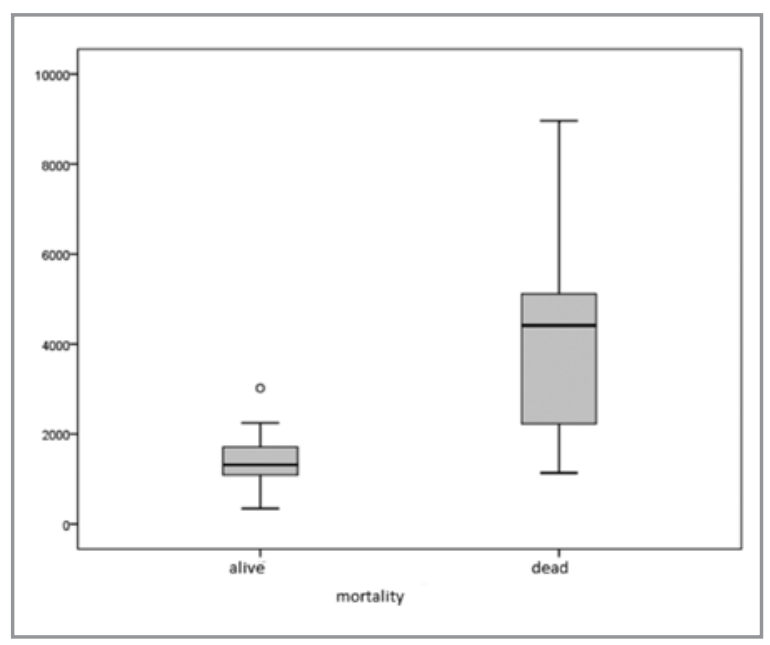

Figure 1. Relationship between adrenomedullin and mortalitiy. between ADM level and mortality $(p<0.001)$. APACHE II score is the most commonly used and most valuable scoring system used to predict mortality in intensive care unit patients. As expected, APACHE II score was higher in non-survivors in our study. The median APACHE II score was 27.8 in non-survivors and 16.9 in survivors $(p<0.001)$. Cut-off value for APACHE II score and ADM were calculated by using ROC curve and the correlation between these two parameters was evaluated (Figure 2). The mortality rate showed a significant increase when ADM level was $>30.19 \mathrm{ng} / \mathrm{L}$ and the AUC in ROC curve analysis was 0.713 for adrenomedullin (Figure 2). The mortality rate showed a significant increase when APACHE II score was $>21$ and the AUC in ROC curve analysis was 0.884 for APACHE II score. In order to prove the value of ADM in mortality of sepsis patients, we evaluated the correlation between ADM and APACHE II score, and there was a significant correlation between these two parameters $(p<0.001$, Pearson's correlation coefficient $=0.487$ ) (Figure 3$)$.

In addition, attempts were made to show relationship between mortality and biomarkers such as proBNP and CRP, which are considered to predict mortality, and complete blood count (CBC). The median proBNP level was $12202.0 \mathrm{pg} / \mathrm{mL}$ in non-survivors and $1882.2 \mathrm{pg} / \mathrm{mL}$ in survivors, as expected nonsurvivors had significantly higher proBNP levels $(p<0.001)$. The cut-off value for proBNP was 3736 $\mathrm{pg} / \mathrm{mL}$ and the $A \cup C$ in ROC curve analysis was 0.703 for proBNP (Figure 2). Although the median CRP value of 201.8 in non-survivors was higher compared to survivors (155.0), the difference was not statistically significant $(p=0.145)$. The relationship between the studied parameters and mortality is presented in (Table 3 ). There was no
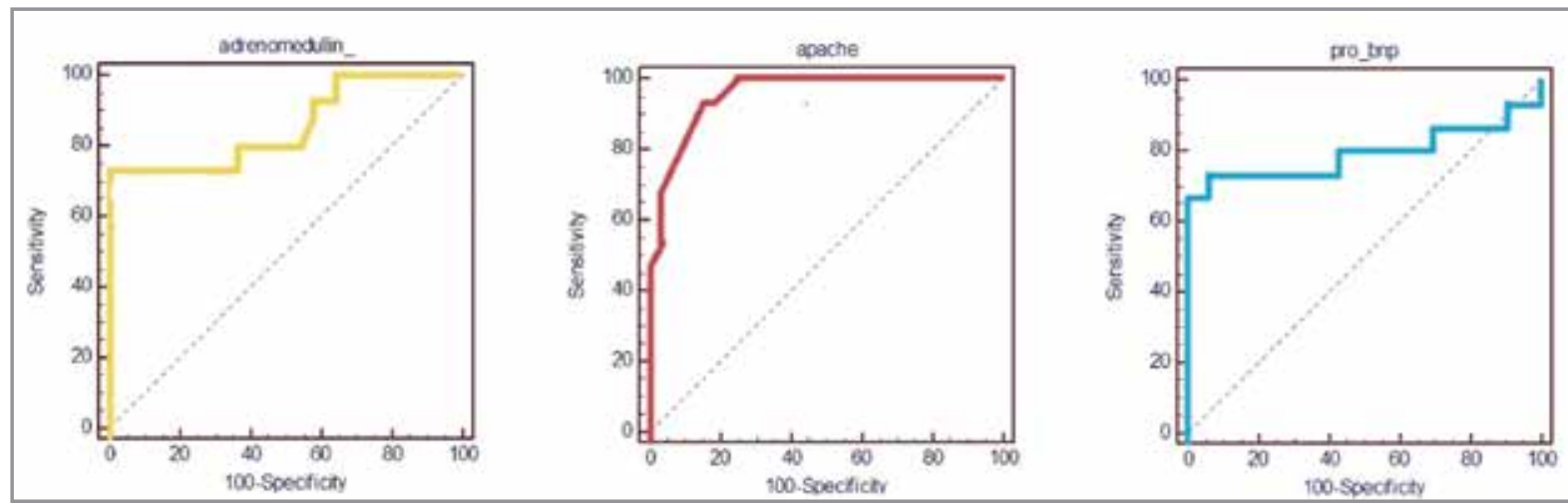

Figure 2. ROC curve analysis for adrenomedullin, APACHE II score and proBNP. 


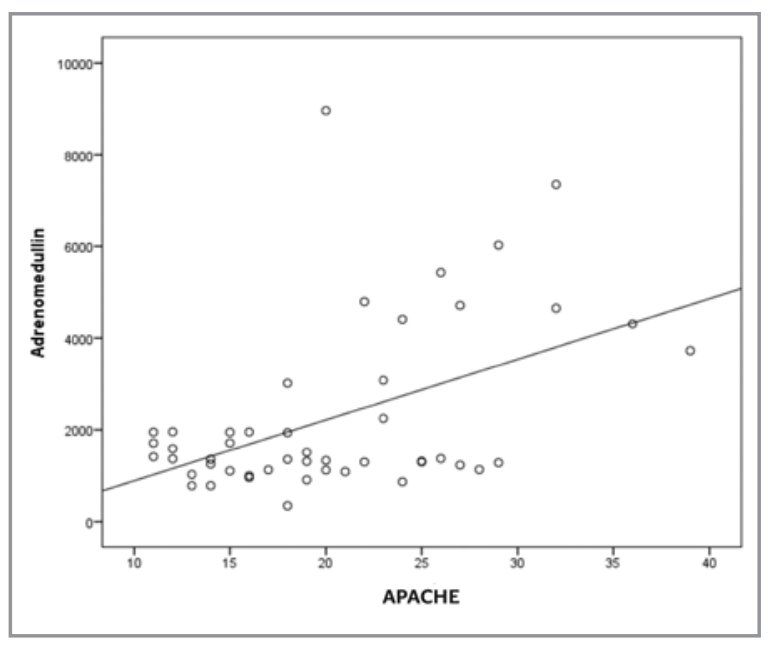

Figure 3. Corrolation between adrenomedullin and APACHE II score.

relationship between mortality and leukocyte count $(p=0.286)$, lower hematocrit $(p=0.964)$ and trombocyte $(p=0.573)$ level (Table 3$)$.

We also attempted to perform risk calculation in these patients. In univariate logistic regression analysis, ADM, proBNP, and APACHE II score appeared as factors influencing mortality $(p<0.05)$. The risk of mortality was 7 -fold higher in patients with adrenomedullin level $>30.1 \mathrm{ng} / \mathrm{L}, 4.2$-fold higher in patients with proBNP level $>3736 \mathrm{pg} / \mathrm{mL}$, and 7.8fold higher in patients with APACHE II score $>21$. Multivariate logistic regression analysis was performed at this stage. APACHE II score was removed from the model since it rendered the model meaningless by causing multiple linear correlations. The risk of mortality was 6.1 -fold higher in patients with proBNP level $>3736 \mathrm{pg} / \mathrm{mL}$. Adrenomedullin level $>30.1 \mathrm{ng} / \mathrm{L}$ was not significant in multivariate analysis (Table 4).

\section{DISCUSSION}

The present study mainly attempted to evaluate the relationship between ADM levels and mortality in patients with sepsis and adrenal insufficiency. The median ADM level was higher in patients with complete adrenal response after ACTH stimulation in the non-survivor group when compared to patients without response to ACTH stimulation. We wanted to prove with this study, if there is not adequate adrenal response, ADM level is not correlated with mortality of sepsis patients. There is not much literature support in adrenal function and ADM level. Worth at al, evaluated adrenal function and ADM level in plasma, they did not show any difference in ADM level in case of hyperaldesteronism and adrenal insufficiency (14).

\begin{tabular}{|c|c|c|c|c|c|}
\hline \multirow[b]{2}{*}{ Diagnosis } & \multicolumn{2}{|c|}{ Dead } & \multicolumn{2}{|c|}{ Alive } & \multirow[b]{2}{*}{ p } \\
\hline & $\mathbf{n}$ & \pm & $\mathbf{n}$ & \pm & \\
\hline Age & 65.0 & 13.41 & 60.00 & 11.14 & 0.196 \\
\hline Adrenomedullin & 41.7 & 39.78 & 13.9 & 582.95 & 0.000 \\
\hline CRP & 201.8 & 112.99 & 155.03 & 100.45 & 0.145 \\
\hline ProBNP & 12202.0 & 12567.84 & 1882.00 & 1652.29 & 0.001 \\
\hline WBC & 14153.3 & 7925.35 & 16651.52 & 25767.36 & 0.286 \\
\hline $\mathrm{Htc}$ & 28.0 & 6.73 & 28.43 & 7.89 & 0.964 \\
\hline Plt & 154087.8 & 104911.30 & 188564.29 & 221529.80 & 0.533 \\
\hline APACHE II & 27.8 & 5.19 & 16.91 & 4.26 & 0.000 \\
\hline
\end{tabular}

Table 4. Regression analysis of adrenomedullin, APACHE II, proBNP

\begin{tabular}{|c|c|c|c|c|c|c|c|c|c|c|c|c|}
\hline & \multicolumn{8}{|c|}{ Univariate logistic regression } & \multicolumn{4}{|c|}{ Multivariate logistic regression } \\
\hline & \multicolumn{2}{|c|}{ Alive } & \multicolumn{2}{|c|}{ Dead } & \multirow[b]{2}{*}{$\mathbf{p}$} & \multirow[b]{2}{*}{ OR } & \multicolumn{2}{|c|}{$95 \%$ C.I. for OR } & \multirow[b]{2}{*}{ p } & \multirow[b]{2}{*}{ OR } & \multicolumn{2}{|c|}{$95 \%$ C.I. for OR } \\
\hline & $\mathbf{n}$ & $\%$ & $\mathbf{n}$ & $\%$ & & & Lower & Upper & & & Lower & Upper \\
\hline Adrenomedullin $>13.68$ & 12 & $36 \%$ & 12 & $80 \%$ & 0.009 & 7.0 & 1.6 & 29.8 & 0.215 & 3.6 & 0.5 & 27.1 \\
\hline ProBNP $>3736$ & 2 & $6 \%$ & 11 & $73 \%$ & 0.000 & 4.2 & 0.6 & 26.6 & 0.002 & 6.1 & 0.4 & 79.2 \\
\hline APACHE II > 21 & 5.0 & $15 \%$ & 14.0 & $93 \%$ & 0.000 & 7.8 & 0.8 & 73.7 & & & - & \\
\hline
\end{tabular}


In this study, we found an increase in plasma ADM levels in patients with sepsis. The mortality increased with increasing plasma ADM level. The studies in the literature suggested that increased plasma ADM level in the intensive care unit patients with sepsis was superior to procalcitonin and CRP that reflect infection status of the patients and offer a more valuable tool in predicting mortality (8-11). In a study that compared survivors and non-survivors, plasma ADM levels were found to be higher in non-survivors compared to survivors (15). By using ROC curve we tried to calculate a cut-off level for ADM; when the level of ADM is over $30.1 \mathrm{ng} / \mathrm{L}$ it predicts mortality with $73 \%$ sensitivity and $100 \%$ specificity. In a similar study, ADM level had $71.4 \%$ sensitivity and $72.7 \%$ specificity in predicting mortality (16). In another study cut off value of ADM was calculated as $41.2 \mathrm{ng} / \mathrm{L}$ in prediction of mortality (17).

The statistical analysis in the present study showed that APACHE II score was superior to ADM in predicting mortality. Although a positive correlation exists between APACHE II score and ADM, APACHE II score remains the most valuable tool in predicting mortality. Similar studies in the literature support this finding. A study similar to the present study compared ADM level and other prognostic markers of sepsis (ie. upar, procalcitonin) and concluded that APACHE II score was the most valuable marker of mortality, and ADM did not perform well as APACHE II score in predicting prognosis (10). Similar to our findings, Travaglino et al. suggested a direct correlation between APACHE II score and ADM level (18).

The study showed that the mortality rate was significantly higher in patients with APACHE II score of 21 and over (sensitivity, 93.3\%; specificity, 84.8\%). Similarly, in a prospective study by Fadaizaeh et al. that evaluated 415 intensive care unit patients, those with APACHE II score of 27 or over had higher mortality rate, and Richards et al. evaluated 278 patients and reported that patients with APACHE II score of 25 or over had higher mortality rate $(19,20)$.

The median CRP value was $155.0 \mathrm{mg} / \mathrm{dL}$ in survivors and $201.8 \mathrm{mg} / \mathrm{dL}$ in non-survivors. The statistical analysis did not show a significant relationship between CRP level and mortality $(p=0.145)$, and we were therefore unable to determine a cut-off level. An increase in CRP level is anticipated in a patient with sepsis due to inflammatory response of the body. Many other studies have also demonstrated increased
CRP levels in patients with sepsis (21-24). We found that mortality rate significantly increased when proBNP levels were above $3736 \mathrm{mg} / \mathrm{dL}$. There are many studies in the literature suggesting a direct correlation between proBNP levels and mortality in patients with sepsis (25-29). Plasma proBNP levels increase with increasing cardiac load and atrial strain; as it would be expected, proBNP levels increase in cases with an increase in the volume load. Therefore, proBNP levels before initiation fluid resuscitation must be taken into consideration while establishing a relationship between proBNP and mortality.

In conclusion although it is not as valuable as APACHE II score, ADM is a very valuable prognostic marker in sepsis patients. ADM level reach higher levels in sepsis only if there is adequate adrenal function; therefore we think that but before measuring ADM level in plasma, first we should evaluate adrenal function.

\section{Limitations}

The present study was a single-centre research and contained a small sample size. Larger sample and multicentre clinical studies will be needed to further investigate the results especially in adrenomedullin level by taking in consideration of adrenal function.

\section{REFERENCES}

1. Dellinger RP. The surviving sepsis campaign: 2013 and beyond. Chin Med I 2013;126:1803-5.

2. Cohen J. The immunopathogenesis of sepsis. Nature 2002; 420:885-91.

3. Kitamura K. [adrenomedullin and related peptides]. Nihon yakurigaku zasshi. Folia Pharmacologica Japonica 1998;112:137-46.

4. Hinson JP, Kapas S, Smith DM. Adrenomedullin, a multifunctional regulatory peptide. Endocr Rev 2000;21:13867.

5. Ehlenz K, Koch B, Preuss P, Simon B, Koop I, Lang RE. High levels of circulating adrenomedullin in severe illness: Correlation with C-reactive protein and evidence against the adrenal medulla as site of origin. Exp Clin Endocrinol Diabetes 1997; 105:156-62.

6. Hirata Y, Mitaka C, Sato K, Nagura T, Tsunoda Y, Amaha K, et al. Increased circulating adrenomedullin, a novel vasodilatory peptide, in sepsis. J Clin Endocrinol Metab 1996;81:144953.

7. Nishio K, Akai Y, Murao Y, Doi N, Ueda S, Tabuse H, et al. Increased plasma concentrations of adrenomedullin correlate with relaxation of vascular tone in patients with septic shock. Crit Care Med 1997;25:953-7. 
8. Debiane L, Hachem RY, Al Wohoush I, Shomali W, Bahu RR, Jiang $Y$, et al. The utility of proadrenomedullin and procalcitonin in comparison to c-reactive protein as predictors of sepsis and bloodstream infections in critically ill patients with cancer. Crit Care Med 2014;42:2500-7.

9. Jordan I, Corniero P, Balaguer M, Ortiz J, Vila D, Velasco J, et al. Adrenomedullin is a useful biomarker for the prognosis of critically ill septic children. Biomark Med 2014;8:1065-72.

10. Suberviola B, Castellanos-Ortega A, Ruiz Ruiz A, LopezHoyos M, Santibanez M. Hospital mortality prognostication in sepsis using the new biomarkers suPAR and proADM in a single determination on ICU admission. Intensive Care Med 2013;39:1945-52.

11. Angeletti S, Battistoni F, Fioravanti M, Bernardini S, Dicuonzo G. Procalcitonin and mid-regional pro-adrenomedullin test combination in sepsis diagnosis. Clin Chem Lab Med CCLM/ FESCC 2013;51:1059-67.

12. Satoh F, Takahashi K, Murakami O, Totsune K, Sone M, Ohneda $M$, et al. Immunocytochemical localization of adrenomedullin-like immunoreactivity in the human hypothalamus and the adrenal gland. Neurosci Lett 1996;203:207-10.

13. Kapas S, Martinez A, Cuttitta F, Hinson JP. Local production and action of adrenomedullin in the rat adrenal zona glomerulosa. J Endocrinol 1998;156:477-84.

14. Vogt $S$, Winkler $E$, Hermsen $D$, Schott $M$, Schinner $S$, Scherbaum WA, et al. Endothelin-1 and adrenomedullin plasma levels after exposure to fludrocortisone, dexamethasone, and spironolactone. Clin Exp Hypertens 2012;34:582-7.

15. Marino R, Struck J, Maisel AS, Magrini L, Bergmann A, Di Somma S. Plasma adrenomedullin is associated with shortterm mortality and vasopressor requirement in patients admitted with sepsis. Crit Care 2014;18:R34.

16. Pezzilli R, Barassi A, Pigna A, Morselli-Labate AM, Imbrogno $A$, Fabbri $D$, et al. Time course of proadrenomedullin in the early phase of septic shock. A comparative study with other proinflammatory proteins. Panminerva Med 2012;54:211-7.

17. Chen YX, Li CS. The predictive value of adrenomedullin for development of severe sepsis and septic shock in emergency department. Biomed Res Int 2013;2013:960101.

18. Travaglino F, De Berardinis B, Magrini L, Bongiovanni C, Candelli $M$, Silveri NG, et al. Utility of procalcitonin (pct) and mid regional pro-adrenomedullin (mr-proadm) in risk stratification of critically ill febrile patients in emergency department (ed). A comparison with apache ii score. BMC Infect Dis 2012;12:184.
19. Fadaizadeh $L$, Tamadon $R$, Saeedfar K, Jamaati HR. Performance assessment of acute physiology and chronic health evaluation ii and simplified acute physiology score ii in a referral respiratory intensive care unit in Iran. Acta Anaesthesiol Taiwan 2012;50:59-62.

20. Richards G, Levy H, Laterre PF, Feldman C, Woodward B, Bates BM, et al. CURB-65, PSI, and APACHE II to assess mortality risk in patients with severe sepsis and community acquired pneumonia in PROWESS. I Intensive Care Med $2011 ; 26: 34-40$.

21. Luzzani A, Polati E, Dorizzi R, Rungatscher A, Pavan R, Merlini A. Comparison of procalcitonin and C-reactive protein as markers of sepsis. Crit Care Med 2003;31:173741.

22. Yentis SM, Soni N, Sheldon J. C-reactive protein as an indicator of resolution of sepsis in the intensive care unit. Intensive Care Med 1995;21:602-5.

23. Castelli GP, Pognani C, Cita M, Stuani A, Sgarbi L, Paladini R. Procalcitonin, C-reactive protein, white blood cells and SOFA score in ICU: diagnosis and monitoring of sepsis. Minerva Anestesiol 2006;72:69-80.

24. Kepa L, Oczko-Grzesik B. [usefulness of plasma C-reactive protein (crp) estimation in patients with bacterial sepsis]. Przegl Epidemiol 2001;55(Suppl 3):S63-S7.

25. Witthaut R, Busch C, Fraunberger P, Walli A, Seidel D, Pilz G, et al. Plasma atrial natriuretic peptide and brain natriuretic peptide are increased in septic shock: Impact of interleukin-6 and sepsis-associated left ventricular dysfunction. Intensive Care Med 2003;29:1696-702.

26. Charpentier J, Luyt CE, Fulla Y, Vinsonneau C, Cariou A, Grabar $S$, et al. Brain natriuretic peptide: $A$ marker of myocardial dysfunction and prognosis during severe sepsis. Crit Care Med 2004;32:660-5.

27. Rudiger $A$, Gasser $S$, Fischler $M$, Hornemann $T$, von Eckardstein A, Maggiorini M. Comparable increase of b-type natriuretic peptide and amino-terminal pro-b-type natriuretic peptide levels in patients with severe sepsis, septic shock, and acute heart failure. Crit Care Med 2006;34:2140-4.

28. Hoffmann $U$, Brueckmann $M$, Bertsch $T$, Wiessner $M$, Liebetrau C, Lang $S$, et al. Increased plasma levels of NT-proANP and NT-proBNP as markers of cardiac dysfunction in septic patients. Clin Lab 2005;51:373-9.

29. Varpula M, Pulkki K, Karlsson S, Ruokonen E, Pettila V. Predictive value of $\mathrm{N}$-terminal pro-brain natriuretic peptide in severe sepsis and septic shock. Crit Care Med 2007; $35: 1277-83$ 